\title{
Diagnostic Accuracy of Ultrasound in Benign Testicular Swelling-A Study of 52 Cases
}

\author{
Authors \\ Dr. Harekrishna Majhi ${ }^{1}$, Dr. Bhupesh Kumar Nayak ${ }^{2}$ \\ ${ }^{1}$ Associate professor, Department of General Surgery, VSS IMSAR, Burla \\ ${ }^{2}$ Senior Resident, Department of General Surgery, VSS IMSAR, Burla \\ Email:majhihk49@gmail.com
}

\begin{abstract}
Testicular swelling is a lump or a growth (mass) involving the genitalia is a common presentation in outdoor patients ranging from young to old. Occur in one or both the testicles. Proper diagnosis can prevent unnecessary surgical exploration to a certain extent where larger groups of non-surgical acute testicular cases co-exist. Most testicular masses are malignant. The main dilemma lies in the diagnosis of the testicular Tumour, of which 99\% of cases are malignant. A testicular lump that doesn't hurt may be a sign of cancer. (Bosl et al, 1981; prout et al, 1984). Although testicular tumour are relatively rare (having an incidence of about $0.01 \%$ of male), they are the most common solid tumour of man aged 15-35 years and second most common tumour of man aged 35-40 years. The advent of Ultrasonography and its application for testicular masses has changed the picture in the recent past. A clinical pattern of testicular swellings with ultrasound was carried out in the Deptt. of General and Laparoscopic Surgery, VSSIMSAR, Burla, Odisha between august 2016 to august 2017

Key Words: ultrasound, benign testicular swelling
\end{abstract}

\section{Introduction}

Bases on physical examination alone, it is often difficult to decide whether a scrotal swelling arises from tesicles it's self or from extra testicular elements in scrotum. Ultrasound was the preferred imaging modality for evaluating patients with scrotal swelling and pain. Doppler analysis allowed detection and diagnosis of abnormalities affecting the vasculature. Scrotal swelling can represent a wide range of medical issues from benign congenital conditions to life threatening malignancies and acute surgical emergencies.

Ultimately surgical exploration corroborates ultrasonographic finding.

\section{Testicular Swelling}

Testicular swelling Most of the time testicular swelling gives dilemma in diagnosis. The possible testicular swellings are enumerated in the chart below. 


\begin{tabular}{|c|c|}
\hline \multicolumn{2}{|c|}{ ICD-9 codes } \\
\hline ICD-9 codes covered if selection criteria are met: \\
\hline 186 & Malignant neoplasm of testis \\
\hline 222 & Benign neoplasm of testis \\
\hline 236.4 & Neoplasm of uncertain of testis \\
\hline 456.4 & Scrotal \\
\hline $603.0-603.9$ & Hydrocele \\
\hline $604.0-604.99$ & Orchitis and epididymitis \\
\hline 608.1 & Torsion of testis \\
\hline $608.20-608.24$ & Atrophy of testis \\
\hline 608.3 & Other injury of external genitals \\
\hline 959.14 & \\
\hline
\end{tabular}

\section{Aims \& Objectives}

To study the diagnostic accuracy of ultrasound benign testicular swelling

Inclusion Criteria:- Any case presenting to the OPD between 10-60 years of age to the Deptt. of General Surgery with scrotal swelling \& pain.

Exclusion Criteria:-Acute or chronic supportive testicular lesions are excluded.

\section{Materials \& Methods}

We collected the data from OPD patients regarding clinical examination, ultrasound investigation, surgical procedure, complications, follow up \& entered into a standard format and the processing was done using Microsoft excel. A clinical pattern of testicular swellings with ultrasound was carried out in the Deptt. of General and Laparoscopic Surgery, VSSIMSAR, Burla, Odisha between august 2016 to august 2017

\section{Ultrasonography in Scrotal Swelling}

Though palpation is the initial and often adequate means of assessment of the scrotum and its contents, its limitations in sensitivity of deeper lesions, in specificity in distinguishing different types of pathology and its impracticability where there is scrotal pain and tenderness means that other methods are often required. Chief among these is ultasonography which is attractive because of its interactiveness acceptance by patients and most important being a non-invasive technique (David O. Cosgrove et al, 1993) ${ }^{28}$.
Immersion and high resolution ultrasonography may aid in the clinical evaluation of the scrotal masses (Friedrich et al, 1981) ${ }^{50}$.

The scrotal contents are well suited to ultrasonographic examination. This was first reported by Miskin and Bain ${ }^{48}$ (1974), who used static B-mode scanning. The advent of high frequency, real time ultrasonography has improved both the ease of examination and the image resolution. Some ultrasound probes have integral waterpaths allowing good "stand off" from the organ of interest and thereby producing an image free from near-field experience.Guthrie and Fowler in $1992^{80}$ had concluded that all patients with scrotal symptoms should be examined by ultrasound in order to achieve maximal clinical benefit from early diagnosis of testicular tumours.

Kennedy PT et al, $1999^{88}$ had shown that the modality using USG can be used to aid the clinician in deciding which patient should undergo orchidectomy, invasive biopsy, or clinical surveillance.

Thinyu and Mutarak, $2008^{92}$ concluded that USG plays an important role in the diagnosis of scrotal disorders and in planning for proper management. Then all the 52 cases were subjected to ultrasonographic examination of scrotal swelling at the Department of Radiodiagnosis, V.S.S. Medical College and Hospital, Burla.

\section{Machine}

Real time (B-Mode) ultrasound scanning with Colour Doppler.

\section{Transducer :}

Philips HD-7 Linear Array Transducer

Frequency $-7.5 \mathrm{MHz}$

\section{Technique of U.S.G.}

Before the patient entered the U.S.G. examination room,proper shaving was done from below umbilicus to mid-thigh region. Then he was laid supine with scrotum exposed. The thighs were fully adducted, a paper towel was put under the scrotum to it. A layer of acoustic coupling gel was applied over the scrotum. Then the well lubricate 
scrotum was stabilized with one hand so that testicular elements could be lined up with the epididymis on a single scan and ultrasonographic examination was the other hand, Serial sagittal and transverse sections were done.

The ultrasonographic features of all 104 testicles were recorded.

Among the 18 cases presented acutely which were suspected for testicular torsion, haematoma clinically or for their exclusion were subjected to colour Doppler ultrasonography. According to the ultrasonographic findings along with history and clinical presentations, 8 cases were subjected to surgical exploration and the rest were managed conservatively with long-term follow up.

All the 34 cases and 39 testicles ( 5 cases presented with bilateral swelling) with chronic presentation suspected to have testicular tumour clinically as well as ultrasonograpically were subjected to operation after preoperative preparation.

\section{Normal Appearances}

Normal testis is of homogenous texture and medium amplitude echogenicity. The mediastinum of the testis is often seen as an echogening band in the long axis of the organ with fine strands radiating into the testicular tissue. The head of the epididymis is slight more echogenic than the testis, while the main length of the epididymis is less echogenic than the adjacent testis (Rifkin et al, 1984) ${ }^{51}$. Leung et al have suggested that the epididymis is relatively more echogenic throughout ${ }^{52}$.

\section{Orchitis}

In the acute state of orchitis, the testis is swollen, remains relatively hypoechoic (Bird and Rosenfield, 1984) ${ }^{53}$. Chronic and low grade inflammation may result in disorganization of scrotal contents, loss of testicular integrity and appearances mimicking tumors. Ischemic, inflammatory and granulomatous orchitis produce similar appearances. Associated skin thickening helps to distinguishing inflammation from malignancy (Subramanyam et al, 1985) ${ }^{54}$.

\section{Actue Epididymitis}

This condition is really diagnosed ultrasonographically by the demonstration of swollen, hypoechoeic epididymis. Such swelling may be gross, with resultant compression and deformity of the adjacent testis. Severe local inflammation (abscess) is seen as areas of focal enlargement with markedly reduced internal echoes, occasionally echo-free and cystic.

\section{Chronic Epididymitis (Periorchitis)}

The most characteristic finding is a thickened tunica albuginea and a thickened somewhat irregular epididymis. Thickening of the fascial covering of the epididymis may be occasionally identified. Calcification is sometimes seen in the tunica albuginea and calculi may form in the between the space (lieskovsky G et al, 1985)55. Adhesions may form between the tunica albuginea and vaginalis, loculating the scrotal fluid that is often in excess. Epididymal cysts or solid fibromas may be detected.

\section{Epididymo-Orchitis}

Focal echo-poor areas are seen in the testis adjacent to most severe epididymil changes. In server epididymo-orchitis, the whole testis may be involved, the appearances than being a combination of acute epididymitis and acute orchitis,

\section{Focal Epididymal Lesions}

Cysts are readily identifiable within the epdidymis. They may become sizeable, particularly in the epididymal head. Multiple cysts within the epididymal head may suggest spermatoceles. Solid lesions of epididymis are often more difficult to define as their echogenicity tends to be comparable with that of the adjacent epididymis. Fibromas and sperm granulomas can be identified, but their appearances are nonspecific. Differenciation of solid from cystic lesions can be performed with ease. (Hamm B et al, 1988)56. 


\section{Hydroceles}

Excess fluid in the scrotum can be readily be visualized. The normal scrotum contains only a few $\mathrm{ml}$ of fluid. If a hydrocele is large and tense there may be considerable compression of the testis with resultant deformity. Ultrasound is of great value in the examination of the testis, rendered impalpable by a large surrounding hydrocele (Hricak H et al, 1983).

\section{Hematoceles And Pyoceles}

These are less common than simple hydroceles. Both hematoceles and pyoceles contain internal septations and loculations. Thickening of the scrotal skin and calcification may be seen in chronic cases (Cunningham JJ et al, 1983)58.

\section{Varicoceles}

The normal testicular veins are ofren visualized with ultrasoud, particularly in the upper scrotum. A varix appears as a collection of tubular structures with no significant inrernal ecgoes, blood flow size of vacuum, no given direction of flow can be

(wolverson et al, 1983) ${ }^{59}$ slight ptessure upon the neck of the scrotum accentuates the phenomenon of direct of flow.

\section{Testicular Trauma}

Trauma of the testis may, in its severest form, , anifest as fracture which can se visualized as diffuse areas of incfeased echogenicty often witnin a hypoechoeic testis, reflecting infarcteon. Haematomas are often confined by the tunica albuginea compressing and defotming the underlying testicular tissue (schaffer,1985) ${ }^{60}$ chronic hematomas appear more hypoechoic to anechoic and tend to decrease in size as they resolve. Ultrasonographic finding suggestive of testicular fracture include heterogenous echopattern of the testicular parenchyma and disruption of the tunica albuginea (Micellef et al, 2001; Buckley \& mc. Aninch, 2006) ${ }^{93}$.

\section{Testicular Torsion}

Torsion of the testis is not easy to diagnose confidently. The ultrasonograpic appearance of torsion may be seen as diffusely or focally hypoechoeic and often swollen. There may be accompanying swelling and reduced echogenicity of the epididymis including echo-free cystic areas of haemorrhage. there is often an increase in fluid in the affected hemiscrotum. Clues to the diagnosis are abnormal position of the testis which may lie transversely or be inverted ("bell and clapper" position) and may be seen to be abnormally mobile (Caeser R.E et al, 1994) ${ }^{62}$.

\section{Focal Intratesticular Lesions}

\section{Cysts-}

Bening cysts of the testis are uncommon. Ultrasound reveals clearly demarcated echo-free lesions with no disorganization of surrounding testicular substance. As some testicular neoplasms may be predominantly cystic, if there is any doubt the normality of surrounding testicular substance, frequent repeated scanning at short intervals is prudent. If any doubt remains, surgical intervention or orchidectomy may be necessary (Keetch D.W. et al, 1991) ${ }^{63}$

\section{Calcified Foci}

Small punctuate areas of calcification may be seen as the result of previous testicular inflammation often in association with testicular atrophy. It is likely that these areas represent efferent tubules containing microscopic speroidal calcified bodies. This is a well-recognised pathological finding at post-mortem but as yet convincing ultrasonic/pathological corroboration is lacking. It is of concern that cases of carcinoma in situ, usually in patients of tumour of the contralateral testis, have been described in association with atrophy of the testis. This represents a worrying and as yet unclear diagnosting problem. Certainly, in patieitns whohave suffered testicular tumour, the finding of microcalcification and/or atrophy within the remaining testis must be of concern. It may be the result of hormonal or humoral effects 
or even of cancer therapy. Some contres perform routine testicular biopsy in such cases (Berger R.C. et al, 1965) ${ }^{65}$

The sonographic pattern of the patients with teratocarcinoma represented the findings of complex cystic space with ireegular margins.On the contrary the seminoma had a very homogenous appearance with sharp border as an ultrasound finding. It was difficult to sifferentiate the other forms of germ cell tumour from teratocarcinoma with the ultrasound picture a close resemblancs between the two. The metastaticneoplasm of the testis had the characteristic of hypoechoeic mass difficult to differentiate from solid variety on ultrasound.

\section{Operation}

Patient was placed in supine position. General anaesthesia was administered.

For the torsed testes which were found to be viable, orchidopex was done. For the case of testicular torsion with non-viable orchidectomy and contralateral orchidopexy was done. Haematocele was drained and testicu;ar contusions were repaired.

The side of the testis, bearing the tumour or suspected to have the tumour were exposed through an inguinal incision. A soft clamp was applied at the highest point of the cord and care was taken not to meddle very much with the testis so as to prevent dissemination of the tumour. Chevassu' manoeuvre was done. Tumours diagnosed by the naked eye examination and Chevassu's manoeuvre were subjected to orchidectomy. Biopsy of the testicular tissue was taken from the suspicious testis and sent for histopathological examination. Then the testes were closed by interrupted absorbanle sutures.

The cases suspected to be benign hydrocele were operated with eversion of sac and for the case with spermatocele was undergone spermatocelectomy via trans-scrotal approach. Varicocelectomy with eversion of sac was done via inguinal approach for the case of varicocele with hydrocele.

\section{Postoperative Management}

Postoperative intravenous fluid, antibiotics were given. Skin stitches were removed on $7^{\text {th }}$ day.

\section{Pathological Study}

The histopathological study was undertaken in the Department of pathology, V.S.S. Medical College and Hospital, Burla.

- Marcoscopic features - the size, shape, surface, colour, consistency and cut section were studied and findings were notes.

- Histopathology - biopsy specimens were rountinely obtained from all cases. The biopsy specimens were transferred to tubes containing $10 \%$ formal saline as preservative. The tissues were then processed in the Department of pathology in histoknette through graded solution of alcohol, xylol and finally embedded in paraffin. The paraffin blocks were prepared. The microsections obtained by the help of a microtome were taken over slides, dried and stained with haematoxylin and eosin. Then the stained slides were studied under microscope both in low (10X) and high power (45X) objectives and histological pattern in each case was noted.

\section{Follow Up:}

The entire patient were observed for imimediate postoperative complications and managed accordingly. All the patients were advised to attend outpatients Department of regular follow up.The patient managed conservatively and postoperative patient without orchidectomy were followed long-term with clinical chedk-up and ultrasonography.

Ultrasonographic examination of the scrotum was done on 52 patients clinically suspected to have testicular swelling. Thus 104 testicles of these patients were included for ultrasonograpic study. Amongst these 47 testicles were found normal onn clinical examination and on evidence of abnormality was found on ultreasonographic study. The remaining 57 testicles suspected and 
subjected to ultrasonography were studies. Among them, 18 cases had acute presentations which were subjected to colour Doppler ultrasonography. The following observations were made.

Final diagnosis in 34 patients and 68 testes

\begin{tabular}{|c|c|c|}
\hline Types Final diagnosis & $\begin{array}{l}\text { No. of } \\
\text { cases }\end{array}$ & $\begin{array}{l}\text { No. of } \\
\text { testis }\end{array}$ \\
\hline Normal & 0 & 29 \\
\hline \multicolumn{3}{|l|}{ Abnormal } \\
\hline Benign & 16 & 19 \\
\hline Cystic & 11 & 11 \\
\hline Hydrocele & 9 & 9 \\
\hline Spermatocele & 1 & 1 \\
\hline Hydrocele with varicocele & 1 & 1 \\
\hline \multirow{6}{*}{$\begin{array}{c}\text { Solid } \\
\text { Granulomatous epidiymis } \\
\text { involving testis } \\
\text { Non-specific chronic } \\
\text { inflammatory testis } \\
\text { Old clotted haematocele }\end{array}$} & \multirow{6}{*}{$\begin{array}{l}1 \\
1\end{array}$} & \multirow{6}{*}{$\begin{array}{l}8 \\
5 \\
2 \\
1\end{array}$} \\
\hline & & \\
\hline & & \\
\hline & & \\
\hline & & \\
\hline & & \\
\hline \multirow{6}{*}{$\begin{array}{c}\text { Malignant } \\
\text { Pure germ cell tumour } \\
\text { Embryonal cell carcinoma } \\
\text { Teratocarcinoma } \\
\text { Yolk sac tumour }\end{array}$} & 18 & 20 \\
\hline & 12 & 12 \\
\hline & 6 & 6 \\
\hline & 2 & 2 \\
\hline & 3 & 3 \\
\hline & 1 & 1 \\
\hline \multicolumn{3}{|l|}{ Mixed germ cell tumour } \\
\hline Embryonal + seminoma & 4 & 4 \\
\hline Embryonal + & 1 & 1 \\
\hline teratocarcinoma & 2 & 2 \\
\hline $\begin{array}{c}\text { Embryonal + yolk sac } \\
\text { tumour }\end{array}$ & 1 & 1 \\
\hline Metastasis & 2 & 4 \\
\hline Secondary metastasis & 2 & 4 \\
\hline Total & 34 & 68 \\
\hline
\end{tabular}

\section{Age Distribution of Acute Swelling}

\begin{tabular}{|c|c|c|c|c|c|c|}
\hline $\begin{array}{c}\text { Age in } \\
\text { years }\end{array}$ & $\begin{array}{c}\text { No.of } \\
\text { cases } \\
\& \\
\text { percen } \\
\text {-tage }\end{array}$ & $\begin{array}{c}\text { No.of } \\
\text { cases } \\
\text { of } \\
\text { torsion } \\
\text { testis } \\
\& \%\end{array}$ & $\begin{array}{c}\text { No. Of } \\
\text { epidid } \\
\text { ymo- } \\
\text { orchiti } \\
\text { s \& } \%\end{array}$ & $\begin{array}{c}\text { No,of } \\
\text { cases } \\
\text { of } \\
\text { orchiti } \\
\text { s \& } \%\end{array}$ & $\begin{array}{c}\text { No.of } \\
\text { case } \\
\text { of } \\
\text { haema } \\
- \\
\text { tocele } \\
\& \%\end{array}$ & $\begin{array}{c}\text { No. Of } \\
\text { case } \\
\text { of } \\
\text { testicu } \\
\text {-lar } \\
\text { constu } \\
\text { sion }\end{array}$ \\
\hline $11-20$ & $\begin{array}{c}84.44 \\
\%\end{array}$ & $\begin{array}{c}16.66 \\
\%\end{array}$ & $\begin{array}{c}16.66 \\
\%\end{array}$ & - & - & $\begin{array}{c}11.11 \\
\%\end{array}$ \\
\hline $21-30$ & $\begin{array}{c}27.77 \\
\%\end{array}$ & $\begin{array}{c}5.55 \\
\%\end{array}$ & $\begin{array}{c}11.11 \\
\%\end{array}$ & $\begin{array}{c}11.11 \\
\%\end{array}$ & - & - \\
\hline $31-40$ & 3 & - & 2 & - & - & - \\
\hline
\end{tabular}

\begin{tabular}{|c|c|c|c|c|c|c|}
\hline & $\begin{array}{c}16.66 \\
\%\end{array}$ & & $\begin{array}{c}11.11 \\
\%\end{array}$ & & & \\
\hline$>40$ & $\begin{array}{c}1 \\
5.55 \\
\%\end{array}$ & - & - & 1 & & \\
& & & $5.55 \%$ & - & - \\
\hline
\end{tabular}

The incidence of testicular torsion was $27.77 \%$ of the cases and came under the age group of 11 to 30 tears. Two cases were prepubertal i.e.at 9 and 11 years of age. The other 3 cases were of.14,16 and 23 years of age.

2 cases of testicular contusion, of age group 21-30 and 1 with heamatocele oe 23 years of age had a history of blunt trauma.

Acute epididymo-orchitis and acute orchitis together constituted $55.55 \%$ of the cases and came under the age group of 11-40 year.

\section{Presentation of Acute Swelling}

\begin{tabular}{|c|c|c|}
\hline Presenting features & No.of cases & Percentage \\
\hline Swelling of testis & 18 & $100 \%$ \\
\hline $\begin{array}{c}\text { Pain over testis and } \\
\text { cord structures }\end{array}$ & 14 & $77.77 \%$ \\
\hline $\begin{array}{c}\text { Pain over testis } \\
\text { alone }\end{array}$ & 3 & $16.66 \%$ \\
\hline $\begin{array}{c}\text { Pain over the } \\
\text { scrotum }\end{array}$ & 2 & $11.11 \%$ \\
\hline Fever (mild) & 0 & $0 \%$ \\
\hline $\begin{array}{c}\text { Nausea and } \\
\text { vomiting }\end{array}$ & 5 & $33.33 \%$ \\
\hline $\begin{array}{c}\text { Absent cremasteric } \\
\text { reflex }\end{array}$ & $67.77 \%$ \\
\hline History of trauma & & \\
\hline
\end{tabular}

14 cases $(77.77 \%)$ presented with pain over testis and cord structure along with swollen testis over one side; among them 9 cases were diagnosed as acute epididymo-orchits which concitituted of $50 \%$ and the other 5 cases came out to be torsion of testis which consitituted of $27.77 \% 2$ cases of acute epididymo-orchitis were encountered mild grade of fever but ultrasonoghaphically there was no evidence of testicular abscess. 5 cases of absent cremasteric reflex were found to be torsion of testis. There was no case with nausea and vomiting. 
3 cases presented with pain swelling over the testis and were diagnosed as orchitis which constituted of $16.66 \%$.

One case $(5.55 \%)$ presented with pain over the scrotum, came out to be haematocele on both sides.

There was history of trauma in 5 cases which constituted of $28.58 \%$ of cases and among the $\mathrm{m} 2$ cases were testicular contusion, 2 cases were orcitis, and 1 case was haematocele.

No case of testicular abscess was encountered.

Pyocele had not been included in this series of study since to eventual tension over testicular vassal; it causes gangrene of the testis of the affected side rather than infecting the testis as such. Though often in young individuals, it is difficult to differentiate this from torsion of testis, no cases of pyocele had been encountered in this series of study.

\section{Presenting Features Of Chronic Testicular Swellings}

\begin{tabular}{|c|c|c|}
\hline Presenting features & $\begin{array}{c}\text { No. of } \\
\text { cases }\end{array}$ & $\begin{array}{c}\text { Percentage } \\
(\%)\end{array}$ \\
\hline $\begin{array}{c}\text { Swelling of testis } \\
\text { including dudpected } \\
\text { testicular swelling (11) }\}\end{array}$ & 34 & 100 \\
\hline Loss of testicular sensation & 15 & 44.11 \\
\hline $\begin{array}{c}\text { Mild tenderness in the } \\
\text { swelling }\end{array}$ & 3 & 8.88 \\
\hline Para-aortic nodes & 1 & 2.94 \\
\hline Hydrocele & 12 & 35.29 \\
\hline Epididymo-orchitis & 5 & 14.7 \\
\hline Varicocele & 1 & 2.94 \\
\hline
\end{tabular}

Of the benign lesions, 11 testes from 11 cases were believed to cystic which represent 9 hydroceles, 1 hydrocele with varicocele and 1 spermatoceles. Out of 9 cases of hydrocele, 5 cases were reactive secondary to epididymitis or epididymo-orchitis. 8 lesions were thought to be solid. Out of theme 5 came out as chronic granulomatous epididymis involving the testis, 2 came out as non-specific inflammation after histopathological study; 2 patietns with chronic granulomatous disease had bilateral involvement. 1 patient had bilateral non-specific chronic inflammatory disease of the testis. 1 patient came out to be an old clotted haematocele.

\section{Age Distribution}

In this study with ultrasonographic examination of scrotum, the presented from the age of 11 to 60 years.

In ths study of acute testicular swelling, majority of cases (13 cases) presented between 11-30 years of age group which consitituted of $72.22 \% .3$ cases of testicular torsion were between 11-20 years of age, 1 case had early presentation before 6 hour and 1 case between 21-30 years of age group. Epididymo-orchitis pressentedfrom 11 to 40 years of age of which majority of cases (3) were from 11-20 years of age. 2 cases of orchitis presented between 21-30 years of age group 2 cases of testicular contusion were between the age group of 11-20 years. 1 case of haematocele was from 31-40 years thus the age incidence of different causes of case in this study simulates with the result of previous study.

\section{Clinical Features}

14 cases constituting $77.77 \%$ presented with acute pain over the testis and cord structures.

Swelling of testis in 23 cases and the rest 11 cases were clinically suspected testicular swelling with associated hydrocele.

Epididymis along with testis was found in 5 cases (35\%)

These were the cases of epididymo-orchitis which is very common in this area.

Hydrocele was found clinically only in 2 cases of testicular tumour (11.11\%)

Mild tenderness with enlargement of the testis was the presenting features in 3 cases $(16.66 \%)$

The palpable abdominal nodes where is 1 case $(5.55 \%)$

\section{Duration of Symptoms}

The duration of symptoms shows 9 cases $(50 \%)$ presented between 3-6 months.

Thus majority of cases presented between 3 month to 9 months following the onset of disease. 


\section{Side of Involvement}

The side of involvement shows the left side of the testis to be involved in 9 cases $(50 \%)$ of testicular tumours. The right side was involved in 7 cases (39\%). Testicular cancer is more common on right side than on the left as reported by Campbell Uro ${ }^{19}$.

\section{Conclusion}

In an attempt to correlate sonographic finding with histopathological features, a prospective study with USG was performed over a period of 25 months.

Most of the acute cases of testicular swelling presented between 11-30 years of age. Majority of the cases were epididymo-orchitis which were 7 in number. 3 cases had acute orchitis and 3 cases had testicular torsion and 1 case was found to be haematocele. Most of the cases presented within 24 hours of developing symptoms. Only 2 cases presented beyond 24 hours, one of which was found to be non-viable torsed testis and the other was epididymo-orchitis.

The sonographic pattern of testicular torsion was reduced or absent blood flow. On the contrary, epididymo-orchitis or orchitis had shown increased blood flow in colour Doppler ultrasonography. It was clearly difeerentiated on CDUS. The case of haematocele was also described as fluid with internal echoes and linear membranes.

The majority of the patient of chronic testicular swelling were between 31-40 years of age. Among the germ cell tumours, there werew 6 cases of seminoma, 3 cases of teratocarcinoman, 2 cases of embryonal cell carcinoma, 1 case of yolk sac tumour, 2 cases of embryonal + teratocarcinoma, 1 case of embryonal+seminoma, 1 case of embryonal+yolk sac tumour, and 2 cases of metastatic testis. All of these presented with a testicular swelling, with absence of testicular sensation in 15 cases $(83.33 \%)$ Early presentation was rare and the majority presented between 2 months of duration of symptoms.
The histopathological findings were corroborated with USG findings. The major group of benign cystic swelling constituted to have hydrocele in 10 cases, hydrocele along with varicocele in 1 case and spermatocele in 1 case. Excess fluid in the tunica was readily visualised by USg and there was no difficulty in the diagnosis.

Of the intrascrotal swelling of testicular origin suspected as tumour by ultrasonography but, diagnosed finally as malignant cases by histopathological examination, majority was found to be seminoma (6 cases) followed by 3 cases of teratocarcinoma. Among the benign cases, inflammation of the testis was found only in 1 case. The rest 1 case was found to be old clotted haematocele.

The benign swelling detected by ultrasound as cystic, on surgical exploration and Chevass's manoeuvre were found to be normal. On regular follow up, no abnormality was detected clinically or on serial ultrasonography.

In the diagnosis of malignant disease where pathological correlation was obtained, this study showed USG to be very accurate. The accuracy in the present study was found to be $79.49 \%$ with a sensitivity of $100 \%$

USG thus has proved accurate in terms of final diagnosis reached as shown in the present study, though in benign disease the final diagnosis is to certain extent speculative due to limited period of follow up.

In case of acute testicular swelling, colour Doppler ultrasonography had proved par excellence compared to traditional grey scale ultrasonography and had diagnosed accurately the cases needed to be explored like the torsion of testis and haematocele. Still taking the limitation of CDUS over missing the case after spontaneous detorsion, surgical exploration of stongly suspected case is still mandatory.

\section{Reference}

1. Pecham MJ, Sokal M, Hendry WH: Bilateral germ cell tumor of testis. Br. J. Uro. 5-158. 
2. Nicholson $\mathrm{P} \mathrm{W}$, Harland $\mathrm{S} \mathrm{J}$ : Inheritance of testicular carcinoma. Br. J. Cancer (1995), 71:421

3. Wilkinson, T.J., B.M. Colls, and P.J Schluter, Increased incidence of germ cell testicular cancer in New Zealand Maoris. Br J Cancer, 1992. 65(5): 769-71.

4. Bosl GJ, Motzer RJ. Testticular germ cell cancer [published correction appears in $\mathrm{N}$ Engl J Med. 1997; 337 (19):1403]. N. Enhl J Med.1997; 337(4):242-253.

5. Garner MJ, Tuner MC, Ghadirian P, Krewski D. Epidemiology of testicular cancer: Int J Cancer. 2005; 116(3):331339.

6. Zdeb M S: the probability of developing carcinoma. AJE, 1977: 106:6

7. Mostofi, D K (1973) Testicular tumours epidemiologic etiologic and pathologic features of Cancer. 32. 1186-1201.

8. Dixon FJ, Moore RA, Atlas of tumour Pathology, Washington DC. Armed forces institute of pathology 1952.

9. Bailey \& Love's Short Practice of Surgery. $22^{\text {nd }}$ edn. 1996: 1006-1008.

10. Kaplan GW, Cromic WC, Lelais PP et al. Prepuratal Yolk sac testicular tumor- a report of

11. Allen F. Morey, Daniel D Dugi. Campbell Uro. 10 edn: 2510

12. Aetna; Clinical Policy Bulletin: Scrotal ultrasound. Number : 0532

13. Emroy TH, Charboneau JW, Randall RV, Scheithauer RW \& Grantham, (1984): Occult testicular interstitial cell tumour in a patient with gynaecomastia, ultrasound detection. Radiology: 151.

14. Lee SH, Back CW, Choi MH, Lee HS MS, Yoon SJ. Trauma to male genital organsL a 10-year review of 156 patients, including 118 treated by surgery. BJU int. jan 2008; 101(2):211-5.

15. Donohue JP, Zachary JN. Distribution of nodal metastasis in no-seminomatous cancer. J. Uro., 1982; 188-315.
16. Leopold GR, Woo VL, Scheible FW, Nachtsheim D, Gosink BB. High resolution ultrasonography of scrotal pathology. Radiology, 1979; 131:719-722.

17. Oliver RT: factors contributing to delay in the diagnosis of testicular tumors: $\mathrm{Br}$. Med.J., 1985: 290-315. 